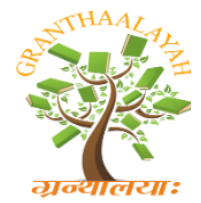

$$
\begin{gathered}
\text { INTERNATIONAL JOURNAL OF RESEARCH - } \\
\text { GRANTHAALAYAH } \\
\text { A knowledge Repository }
\end{gathered}
$$

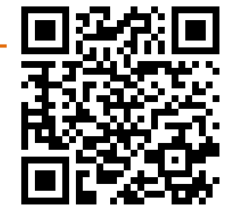

Management

\title{
FARMERS' UNDERSTANDING TOWARD THE WAREHOUSE RECEIPT SYSTEM'S POLICY IN EAST JAVA INDONESIA
}

\author{
Sulistyaningsih $^{1}$, Rudi Wibowo ${ }^{2}$, Yuli Hariyati ${ }^{3}$, Evita Soliha Hani ${ }^{4}$ \\ ${ }^{1}$ Department of Agribusiness, Faculty of Agriculture, University of Abdurachman Saleh, \\ Indonesia \\ 2, 3, 4 Department of Agribusiness, Faculty of Agriculture, University of Jember, \\ Indonesia
}

\begin{abstract}
This study examined farmers' understanding toward the Warehouse Receipt System (WRS) policy in East Java, Indonesia. It focused on 16 question items, namely 1) WRS existence, 2) WRS definition, 3) WRS rules, 4) WRS function, 5) WRS to prevent risks, 6) WRS as a marketing solution, 7) types of commodities stored in warehouse, 8) warehouse receipt as collateral, 9) security of the stored goods, 10) insurance for the stored goods, 11) WRS to solve issue related to capital, 12) WRS facilities, 13) WRS services, 14) time allotment to publish warehouse receipt, 15) storage procedures, 16) institution/ individual associated to WRS. The study was conducted in six districts, Sampang, Probolinggo, Situbondo, Madiun, Nganjuk, Tuban. The data analysis was Likert scale. Item 14 had the highest result with total score of $116(64.4 \%)$ It meant the respondents (farmers) understood they had to wait 1 or 2 days between storage process and publishing the receipt. Item 16 had the lowest result with total score of 84 (46.7\%) meaning the respondents quite understood that warehouse manager, financial institution (bank) and quality control staffs were people involved in the management of WRS. Having obtained the data from farmers that did not use WRS it was found that item 7 had the highest score (177 or 59\%). It implied that the respondents quite understood that grain, corn and rice were the types of commodities that they could store in the warehouse. However, most of the respondents were not aware that they could store other commodities such as coffee, chocolate, and salt in the warehouse.
\end{abstract}

Keywords: Warehouse Receipt System (WRS); Policy; Farmers’ Understanding.

Cite This Article: Sulistyaningsih, Rudi Wibowo, Yuli Hariyati, and Evita Soliha Hani. (2019). "FARMERS' UNDERSTANDING TOWARD THE WAREHOUSE RECEIPT SYSTEM'S POLICY IN EAST JAVA INDONESIA." International Journal of Research - Granthaalayah, 7(5), 152-169. https://doi.org/10.29121/granthaalayah.v7.i5.2019.833.

\section{Introduction}

Declining price of commodity during harvest took place in Indonesia every year. Small farmers are the one who suffer the most. Farmers cannot save their harvest for a long time due to financial 
reason and they do not have adequate storage facilities. Middleman and shark loan are always taking advantage of this condition. The middlemen work for wholesaler or large private warehouse owners (Sustyaningrum Evi, 2014).

Having spent their money for farming and daily expenses farmers are forced to sell their harvest in such a low price. Farmers need a relatively large storage to keep their crops. In addition, without appropriate treatment, these crops are prone to damage, for example by pests (Haryani, 2010).

One characteristic of agricultural commodities is its seasonal production. Each harvest time, prices of these seasonal crops plummeted. Therefore, an alternative marketing model that allows farmers to store their harvest and wait for decent prices before them is needed.

Based on the field observation, price of rice increased drastically between Rp.7,500/kg and Rp.12,300/kg depend upon which area it is sold. Price of dried unhull rice is between Rp.3,200/kg and Rp.5,100/kg. This price fluctuation affects the economy and availability of food. It shows how much risks farmers should take every harvest time. To overcome this problem, new pattern of marketing and harvest management that will benefit the farmers should be implemented.

One alternative to solve the problem above is through a warehouse receipt system. Sudarjat (2014) stated that delaying the sale of food commodities until prices got back to normal would help overcoming business risk. However, some farmers may not have enough funding for the next farming season when there is delay in food commodity sales. Therefore, the solution is warehouse receipt financing that use food commodity as inventory collateral.

Warehouse receipt system (WRS), in its application, can strengthen food reserve. Some obstacles in its implementation are: lacking understanding on WRS, limited warehouse facility (infrastructure), lack of local government involvement, and limited financial aid (Anonymous, 2012).

According to the Directorate of Agricultural Financing, Directorate General of Infrastructure and Agricultural Facility of the Ministry of Agriculture (2011) these are some obstacles during the implementation of WRS in some areas in Indonesia.

- Most of the lands are narrow so it is difficult to consolidate the results;

- Farmer's and supervisor's lacking managerial skills;

- Farmer's and supervisor's lacking understanding about WRS;

- High operating cost.

In East Java, the implementation of WRS has not been optimum. Besides the issues stated previously, slow development of WRS warehouse also contribute to the poor implementation of WRS in East Java. There are 99 WRS warehouses across Indonesia, 30 of which are located in East Java. These warehouses are storage facilities that farmers have yet to take advantage of properly. Therefore, it is important to conduct deeper and further studies focusing on farmers' understanding to the Warehouse Receipt System policy in East Java in order to develop a successful WRS. Objectives of this analysis are to describe the farmers' understanding about WRS implementation and to gain some insights for developing WRS in the future. It is expected that 
implementation of WRS meets its initial goals, improves farmer's financial condition, and helps to develop the national economy.

It is expected that WRS can run according to the plan for the sake of farmer's welfare, food's stability, and the development of national economy. According to Husodo (2004), food is a commodity which is important and strategic because it is human basic need which should be fulfilled every time. Therefore, sufficient food should be consumable, affordable, and available everywhere. One of indicators of successful farming development is the increase of income and welfare of farmers who live in villages. (Mardikanto, 2009)

\section{Methods}

The setting of this study was East Java since East Java has implemented Warehouse Receipt System. The samples were farmers/farmer groups that used warehouse (WRS users), those who did not use the warehouse (non WRS user) and some institutions/ individuals associated to Warehouse Receipt System. Based on Roscoe, appropriate sample size in a study is between 30 and 500 (Sugiyono, 2009).

The techniques of collecting the data were survey, interviews, and discussions/FGDs, while the key informants were the representatives from the WRS users, non WRS users and institutions/ individuals associated to Warehouse Receipt System. The stages in selecting the key informants were:

- $\quad$ Identifying clusters based on districts.

- WRS warehouses in East Java were represented by six districts and one municipality from each districts was selected as WRS warehouse sample.

- $\quad$ Randomly selecting the municipalities in the WRS Warehouse were located (Sampang, Situbondo, Probolinggo, Nganjuk, Madiun, Tuban)

- $\quad$ Selecting informants.

The data analysis technique used in this study was Likert scale (Nasir Muhamad, 2013). The data analysis steps were:

1) Selecting 5-point Likert scale

2) Developing 16 questions (positive) and alternative responses based on the criteria (Anonymous, 2015), namely:

- $\quad$ Very Unfamiliar (VUF) $=1$

- $\quad$ Do not understand $(\mathrm{DNU})=2$

- $\quad$ Fairly understand (QU) $=3$

- $\quad$ Understand (U) $\quad=4$

- $\quad$ Really understand (VU) $=5$

3) Developing rubric for the research indicators and calculating the results questionnaires using checklist.

\section{Results}

Development of WRS in East Java remained stagnant. In some areas, the WRS warehouses were no longer functioning properly; they were empty, and dirty and some of them had never been used 
since the warehouses were built. There were poorly taken care of and there were some damaged on the buildings such as the roof. Factors influencing farmers' understanding on WRS are very complex, such as: existence of WRS, definitions, rules, function, storage procedures and etc. In this study, the respondents were divided into two groups: WRS users and non WRS users.

\subsection{Users' Understanding on the Warehouse Receipt System}

The 16 question items were 1) WRS existence, 2) WRS definition, 3) WRS rules, 4) WRS function, 5) WRS to prevent risks, 6) WRS as a marketing solution, 7) types of commodities stored in warehouse, 8) warehouse receipt as collateral, 9) security of the stored goods, 10) insurance for the stored goods, 11) WRS to solve issue related to capital, 12) WRS facilities, 13) WRS services, 14) time allotment to publish warehouse receipt, 15) storage procedures, 16) institution/ individual associated to WRS. The findings were discussed based on every municipality that became the setting of the study.

\section{Probolinggo}

Table 1: WRS User's Understanding on WRS Policy in Probolinggo

\begin{tabular}{|c|c|c|c|c|c|c|c|c|c|}
\hline \multirow[t]{2}{*}{ No } & \multirow[t]{2}{*}{ Question } & \multicolumn{5}{|c|}{ Number of Respondents' Answer } & \multirow{2}{*}{$\begin{array}{l}\text { Total } \\
\text { score }\end{array}$} & \multirow{2}{*}{$\begin{array}{l}\text { Score } \\
\text { interpretation } \\
(\%)\end{array}$} & \multirow[t]{2}{*}{ Criteria } \\
\hline & & $\begin{array}{l}\text { VUF } \\
=1\end{array}$ & $\begin{array}{l}\text { DNU } \\
=2\end{array}$ & $\begin{array}{l}\mathbf{Q U} \\
=\mathbf{3}\end{array}$ & $\begin{array}{l}\text { U } \\
=4\end{array}$ & $\begin{array}{l}\text { VU } \\
=5\end{array}$ & & & \\
\hline 1 & Item 1 & 0 & 0 & 8 & 2 & 0 & 32 & 64 & $\mathrm{U}$ \\
\hline 2 & Item 2 & 0 & 0 & 10 & 0 & 0 & 30 & 60 & $\mathrm{U}$ \\
\hline 3 & Item 3 & 0 & 8 & 2 & 0 & 0 & 22 & 44 & QU \\
\hline 4 & Item 4 & 0 & 0 & 10 & 0 & 0 & 30 & 60 & $\mathrm{U}$ \\
\hline 5 & Item 5 & 0 & 0 & 10 & 0 & 0 & 30 & 60 & $\mathrm{U}$ \\
\hline 6 & Item 6 & 0 & 0 & 10 & 0 & 0 & 30 & 60 & $\mathrm{U}$ \\
\hline 7 & Item 7 & 0 & 0 & 8 & 2 & 0 & 32 & 64 & $\mathrm{U}$ \\
\hline 8 & Item 8 & 0 & 0 & 10 & 0 & 0 & 30 & 60 & $\mathrm{U}$ \\
\hline 9 & Item 9 & 0 & 0 & 10 & 0 & 0 & 30 & 60 & $\mathrm{U}$ \\
\hline 10 & Item 10 & 0 & 0 & 10 & 0 & 0 & 30 & 60 & $\mathrm{U}$ \\
\hline 11 & Item 11 & 0 & 0 & 10 & 0 & 0 & 30 & 60 & $\mathrm{U}$ \\
\hline 12 & Item 12 & 0 & 1 & 7 & 2 & 0 & 31 & 62 & $\mathrm{U}$ \\
\hline 13 & Item 13 & 0 & 0 & 10 & 0 & 0 & 30 & 60 & $\mathrm{U}$ \\
\hline 14 & Item 14 & 0 & 0 & 4 & 6 & 0 & 36 & 72 & $\mathrm{U}$ \\
\hline 15 & Item 15 & 0 & 0 & 8 & 2 & 0 & 32 & 64 & $\mathrm{U}$ \\
\hline 16 & Item 16 & 0 & 8 & 2 & 0 & 0 & 22 & 44 & QU \\
\hline & Total & & & & & & 477 & 954 & \\
\hline & Average & & & & & & 29.8 & 59.6 & QU \\
\hline
\end{tabular}

Source: Data Analysis, 2017

Table 1 showed how much WRS users who lived in Probolinggo understood the WRS policy. The total respondents were 10 (ten). Item 14, time allotment to publish got the highest total score (72\%) It showed that the WRS users understood how much time needed to issue WRS receipt. Then, Item 3 , WRS rules, and 16, institution/ individual associated to WRS had the lowest score. The 
percentages were $44 \%$ and $44 \%$ respectively. It meant the WRS users had fair understanding on WRS rules and institutions/ individuals associated to WRS.

\section{Sampang}

Table 2: WRS Users' Understanding on WRS Policy in Sampang

\begin{tabular}{|c|c|c|c|c|c|c|c|c|c|}
\hline \multirow[t]{2}{*}{ No } & \multirow[t]{2}{*}{ Question } & \multicolumn{5}{|c|}{$\begin{array}{c}\text { Number of respondents' } \\
\text { Answers }\end{array}$} & \multirow[t]{2}{*}{$\begin{array}{l}\text { Total } \\
\text { score }\end{array}$} & \multirow{2}{*}{$\begin{array}{c}\text { Score } \\
\text { Interpretation } \\
(\%)\end{array}$} & \multirow[t]{2}{*}{ Criteria } \\
\hline & & $\begin{array}{c}\text { VUF } \\
=1\end{array}$ & $\begin{array}{c}\text { DNU } \\
=2\end{array}$ & $\begin{array}{l}\text { QU } \\
=3\end{array}$ & $\begin{array}{c}\mathrm{U} \\
=4\end{array}$ & $\begin{array}{l}\text { VU } \\
=5\end{array}$ & & & \\
\hline 1 & Item 1 & 0 & 0 & 3 & 0 & 0 & 9 & 60 & $\mathrm{U}$ \\
\hline 2 & Item 2 & 0 & 0 & 3 & 0 & 0 & 9 & 60 & $\mathrm{U}$ \\
\hline 3 & Item 3 & 0 & 0 & 3 & 0 & 0 & 9 & 60 & $\mathrm{U}$ \\
\hline 4 & Item 4 & 0 & 0 & 3 & 0 & 0 & 9 & 60 & $\mathrm{U}$ \\
\hline 5 & Item 5 & 0 & 0 & 3 & 0 & 0 & 9 & 60 & $\mathrm{U}$ \\
\hline 6 & Item 6 & 0 & 0 & 3 & 0 & 0 & 9 & 60 & $\mathrm{U}$ \\
\hline 7 & Item 7 & 0 & 0 & 0 & 3 & 0 & 12 & 80 & VU \\
\hline 8 & Item 8 & 0 & 0 & 3 & 0 & 0 & 9 & 60 & $\mathrm{U}$ \\
\hline 9 & Item 9 & 0 & 0 & 3 & 0 & 0 & 9 & 60 & $\mathrm{U}$ \\
\hline 10 & Item 10 & 0 & 0 & 3 & 0 & 0 & 9 & 60 & $\mathrm{U}$ \\
\hline 11 & Item 11 & 0 & 1 & 2 & 0 & 0 & 8 & 53 & $\mathrm{QU}$ \\
\hline 12 & Item 12 & 0 & 0 & 3 & 0 & 0 & 9 & 60 & $\mathrm{U}$ \\
\hline 13 & Item 13 & 0 & 0 & 3 & 0 & 0 & 9 & 60 & $\mathrm{U}$ \\
\hline 14 & Item 14 & 0 & 0 & 1 & 2 & 0 & 11 & 73 & $\mathrm{U}$ \\
\hline 15 & Item 15 & 0 & 0 & 3 & 0 & 0 & 9 & 60 & $\mathrm{U}$ \\
\hline 16 & Item 16 & 0 & 1 & 2 & 0 & 0 & 8 & 53 & QU \\
\hline & Total & & & & & & 147 & 967 & \\
\hline & Average & & & & & & 9.2 & 60.4 & $\mathrm{U}$ \\
\hline
\end{tabular}

Source: Data Analysis, 2017

There are 3 respondents in Sampang. Item 7 had the highest score (12 or $80 \%)$ showing that the WRS users had high understanding towards which types of commodity they may store in the warehouses. Item 11 and 16 had the lowest score (8 or 53\%). It showed that the WRS users had fair understanding that WRS helped solving issues related to capital and equal understanding on institutions/ individuals associated to WRS. The average score was 9.2 or $60.4 \%$ which showed the WRS users in Sampang had understood the WRS policy.

\section{Nganjuk}

Table 3: WRS Users' Understanding on WRS Policy in Nganjuk

\begin{tabular}{|c|c|c|c|c|c|c|c|c|c|}
\hline \multirow[b]{2}{*}{ No } & \multirow[b]{2}{*}{ Question } & \multicolumn{5}{|c|}{ Number of Respondents' Answers } & \multirow[b]{2}{*}{$\begin{array}{l}\text { Total } \\
\text { score }\end{array}$} & \multirow{2}{*}{$\begin{array}{l}\text { Score } \\
\text { Interpretation } \\
(\%)\end{array}$} & \multirow[b]{2}{*}{ Criteria } \\
\hline & & $\begin{array}{l}\text { VUF } \\
=1\end{array}$ & $\begin{array}{l}\text { DNU } \\
=2\end{array}$ & $\begin{array}{l}\text { QU } \\
=3\end{array}$ & $\begin{array}{l}\mathrm{U} \\
=4\end{array}$ & $\begin{array}{l}\mathrm{VU} \\
=5\end{array}$ & & & \\
\hline 1 & Item 1 & 0 & 0 & 3 & 0 & 0 & 9 & 60 & $\mathrm{U}$ \\
\hline 2 & Item 2 & 0 & 1 & 2 & 0 & 0 & 8 & 53 & QU \\
\hline
\end{tabular}




\begin{tabular}{|l|l|l|l|l|l|l|l|l|l|}
\hline 3 & Item 3 & 0 & 0 & 3 & 0 & 0 & 9 & 60 & $\mathrm{U}$ \\
\hline 4 & Item 4 & 0 & 0 & 3 & 0 & 0 & 9 & 60 & $\mathrm{U}$ \\
\hline 5 & Item 5 & 0 & 0 & 3 & 0 & 0 & 9 & 60 & $\mathrm{U}$ \\
\hline 6 & Item 6 & 0 & 0 & 3 & 0 & 0 & 9 & 60 & $\mathrm{U}$ \\
\hline 7 & Item 7 & 0 & 0 & 1 & 2 & 0 & 11 & 73 & $\mathrm{U}$ \\
\hline 8 & Item 8 & 0 & 0 & 3 & 0 & 0 & 9 & 60 & $\mathrm{U}$ \\
\hline 9 & Item 9 & 0 & 0 & 3 & 0 & 0 & 9 & 60 & $\mathrm{U}$ \\
\hline 10 & Item 10 & 0 & 0 & 3 & 0 & 0 & 9 & 60 & $\mathrm{U}$ \\
\hline 11 & Item 11 & 0 & 0 & 3 & 0 & 0 & 9 & 60 & $\mathrm{U}$ \\
\hline 12 & Item 12 & 0 & 1 & 2 & 0 & 0 & 8 & 53 & $\mathrm{QU}$ \\
\hline 13 & Item 13 & 0 & 0 & 3 & 0 & 0 & 9 & 60 & $\mathrm{U}$ \\
\hline 14 & Item 14 & 0 & 0 & 3 & 0 & 0 & 9 & 60 & $\mathrm{U}$ \\
\hline 15 & Item 15 & 0 & 1 & 2 & 0 & 0 & 8 & 53 & $\mathrm{QU}$ \\
\hline 16 & Item 16 & 0 & 0 & 3 & 0 & 0 & 9 & 60 & $\mathrm{U}$ \\
\hline & Total & & & & & & 143 & 952 & $\mathrm{QU}$ \\
\hline & Average & & & & & 8.9 & 59.5 & \\
\hline
\end{tabular}

Source: Data Analysis, 2017

The number of respondents in Nganjuk was 3 respondents. Item 7 had the highest score (12 or $80 \%$ ) showing that the WRS users had high understanding towards which types of commodity they may store in the warehouses Item 2 and 12 had the lowest score ( 8 or 53\%) each meaning that the farmers fair understanding on WRS. These farmers had attended WRS socialization previously so they knew the definition of WRS. In addition, the farmers who used WRS warehouses also had fair understanding about facilities in WRS warehouses such as dryer, and scale. The average score is 8.9 or $59.5 \%$ which meant that farmers who used WRS warehouses fairly understood the WRS policy.

\section{Madiun}

Table 4: WRS Users' Understanding on WRS Policy in Madiun

\begin{tabular}{|c|c|c|c|c|c|c|c|c|c|}
\hline \multirow[b]{2}{*}{ No } & \multirow[b]{2}{*}{ Question } & \multicolumn{5}{|c|}{ Number of Respondents' Answers } & \multirow[b]{2}{*}{$\begin{array}{l}\text { Total } \\
\text { score }\end{array}$} & \multirow{2}{*}{$\begin{array}{l}\text { Score } \\
\text { Interpretation } \\
(\%)\end{array}$} & \multirow[b]{2}{*}{ Criteria } \\
\hline & & $\begin{array}{l}\text { VUF } \\
=1\end{array}$ & $\begin{array}{l}\text { DNU } \\
=2\end{array}$ & $\begin{array}{l}\text { QU } \\
=3\end{array}$ & $\begin{array}{l}\mathrm{U} \\
=4\end{array}$ & $\begin{array}{l}\text { VU } \\
=5\end{array}$ & & & \\
\hline 1 & Item 1 & 0 & 1 & 8 & 1 & 0 & 30 & 60 & $\mathrm{U}$ \\
\hline 2 & Item 2 & 0 & 9 & 1 & 0 & 0 & 21 & 42 & QU \\
\hline 3 & Item 3 & 0 & 6 & 4 & 0 & 0 & 24 & 48 & QU \\
\hline 4 & Item 4 & 0 & 0 & 9 & 1 & 0 & 31 & 62 & $\mathrm{U}$ \\
\hline 5 & Item 5 & 0 & 1 & 9 & 0 & 0 & 29 & 58 & QU \\
\hline 6 & Item 6 & 0 & 0 & 9 & 1 & 0 & 31 & 62 & $\mathrm{U}$ \\
\hline 7 & Item 7 & 0 & 0 & 10 & 0 & 0 & 30 & 60 & $\mathrm{U}$ \\
\hline 8 & Item 8 & 0 & 0 & 10 & 0 & 0 & 30 & 60 & $\mathrm{U}$ \\
\hline 9 & Item 9 & 0 & 0 & 9 & 1 & 0 & 31 & 62 & $\mathrm{U}$ \\
\hline 10 & Item 10 & 0 & 2 & 8 & 0 & 0 & 28 & 56 & QU \\
\hline 11 & Item 11 & 0 & 0 & 10 & 0 & 0 & 30 & 60 & $\mathrm{U}$ \\
\hline 12 & Item 12 & 0 & 2 & 7 & 1 & 0 & 29 & 58 & QU \\
\hline
\end{tabular}




\begin{tabular}{|l|l|l|l|l|l|l|l|l|l|}
\hline 13 & Item 13 & 0 & 0 & 10 & 0 & 0 & 30 & 60 & $\mathrm{U}$ \\
\hline 14 & Item 14 & 0 & 1 & 8 & 1 & 0 & 30 & 60 & $\mathrm{U}$ \\
\hline 15 & Item 15 & 0 & 3 & 6 & 1 & 0 & 28 & 56 & QU \\
\hline 16 & Item 16 & 0 & 7 & 3 & 0 & 0 & 23 & 46 & QU \\
\hline & Total & & & & & & 455 & 910 & \\
\hline & Average & & & & & & 28.4 & 56.8 & QU \\
\hline
\end{tabular}

Source: Data Analysis, 2017

The total respondents in Madiun were 10 respondents. Item 4, 6 and 9 had the highest score (31or $62 \%$ each) meaning that the WRS users understood the function of WRS, WRS as a marketing solution for agricultural products and that the crops stored in the warehouse were insured. Item 2 had the lowest score ( 21 or $42 \%$ ) which meant the farmers had fair understanding on the definition of WRS because of WRS socialization they attended previously. The average score is 28.4 or $56.8 \%$, which showed that the farmers in Madiun understood the overall WRS policy.

\section{Tuban}

Table 5: WRS Users' Understanding on WRS Policy in Tuban

\begin{tabular}{|c|c|c|c|c|c|c|c|c|c|}
\hline \multirow[b]{2}{*}{ No } & \multirow[b]{2}{*}{ Question } & \multicolumn{5}{|c|}{ Number of Respondents' Answers } & \multirow[b]{2}{*}{$\begin{array}{l}\text { Total } \\
\text { score }\end{array}$} & \multirow{2}{*}{$\begin{array}{l}\text { Score } \\
\text { Interpretation } \\
(\%)\end{array}$} & \multirow[b]{2}{*}{ Criteria } \\
\hline & & $\begin{array}{l}\text { VUF } \\
=1\end{array}$ & $\begin{array}{l}\text { DNU } \\
=2\end{array}$ & $\begin{array}{l}\text { QU } \\
=3\end{array}$ & $\begin{array}{l}\mathrm{U} \\
=4\end{array}$ & $\begin{array}{l}\text { VU } \\
=5\end{array}$ & & & \\
\hline 1 & Item 1 & 0 & 2 & 8 & 0 & 0 & 28 & 56 & QU \\
\hline 2 & Item 2 & 0 & 8 & 2 & 0 & 0 & 22 & 44 & QU \\
\hline 3 & Item 3 & 0 & 7 & 3 & 0 & 0 & 23 & 46 & QU \\
\hline 4 & Item 4 & 0 & 0 & 10 & 0 & 0 & 30 & 60 & $\mathrm{U}$ \\
\hline 5 & Item 5 & 0 & 1 & 9 & 0 & 0 & 29 & 58 & QU \\
\hline 6 & Item 6 & 0 & 2 & 8 & 0 & 0 & 28 & 56 & QU \\
\hline 7 & Item 7 & 0 & 0 & 10 & 0 & 0 & 30 & 60 & $\mathrm{U}$ \\
\hline 8 & Item 8 & 0 & 0 & 10 & 0 & 0 & 30 & 60 & $\mathrm{U}$ \\
\hline 9 & Item 9 & 0 & 0 & 10 & 0 & 0 & 30 & 60 & $\mathrm{U}$ \\
\hline 10 & Item 10 & 0 & 2 & 8 & 0 & 0 & 28 & 56 & QU \\
\hline 11 & Item 11 & 0 & 0 & 10 & 0 & 0 & 30 & 60 & $\mathrm{U}$ \\
\hline 12 & Item 12 & 0 & 1 & 9 & 0 & 0 & 29 & 58 & QU \\
\hline 13 & Item 13 & 0 & 2 & 8 & 0 & 0 & 28 & 56 & QU \\
\hline 14 & Item 14 & 0 & 0 & 10 & 0 & 0 & 30 & 60 & $\bar{U}$ \\
\hline 15 & Item 15 & 0 & 5 & 5 & 0 & 0 & 25 & 50 & QU \\
\hline 16 & Item 16 & 0 & 8 & 2 & 0 & 0 & 22 & 44 & QU \\
\hline & Total & & & & & & 442 & 884 & \\
\hline & Average & & & & & & 28.4 & 55.2 & $\mathrm{U}$ \\
\hline
\end{tabular}

Source: Data Analysis, 2017

The number of respondents in Tuban was 10 respondents. Item 4, 7, 8, 9, 11 and 14 had the highest score (30 or $60 \%$ each).It showed that the WRS users had understanding on the function of WRS, the commodities to store in the warehouse, warehouse receipt as collateral in the bank, the WRS storage security, effectiveness of WRS to overcome problems related to capital and time allotment 
until a receipt being published. Item 2 and 16 had the lowest score ( 22 or $44 \%$ each meaning). It inferred that the farmers had fair understanding on the definition of WRS and institutions/ individuals associated to WRS because of WRS socialization they attended previously. The average score was 28.4 or $55.2 \%$ which meant WRS users in Tuban understood the overall WRS policy.

\section{East Java}

Table 6 described the result of the data analysis from from 36 WRS users from six municipalities in East Java (Tuban, Madiun, Nganjuk, Sampang, Probolinggo, and Situbondo).

Table 6: WRS Users' Understanding on WRS Policy in East Java

\begin{tabular}{|c|c|c|c|c|c|c|c|c|c|}
\hline \multirow[b]{2}{*}{ No } & \multirow[b]{2}{*}{ Question } & \multicolumn{5}{|c|}{ Number of Respondents' Answers } & \multirow[b]{2}{*}{$\begin{array}{l}\text { Total } \\
\text { score }\end{array}$} & \multirow{2}{*}{$\begin{array}{l}\text { Score } \\
\text { Interpretation } \\
(\%)\end{array}$} & \multirow[b]{2}{*}{ Criteria } \\
\hline & & $\begin{array}{l}\text { VUF } \\
=1\end{array}$ & $\begin{array}{l}\text { DNU } \\
=2\end{array}$ & $\begin{array}{l}\text { QU } \\
=3\end{array}$ & $\begin{array}{l}\mathrm{U} \\
=4\end{array}$ & $\begin{array}{l}\mathrm{VU} \\
=5\end{array}$ & & & \\
\hline 1 & Item 1 & 0 & 3 & 30 & 3 & 0 & 108 & 60 & $\mathrm{U}$ \\
\hline 2 & Item 2 & 0 & 18 & 18 & 0 & 0 & 90 & 50 & QU \\
\hline 3 & Item 3 & 0 & 21 & 15 & 0 & 0 & 87 & 48.3 & QU \\
\hline 4 & Item 4 & 0 & 0 & 35 & 1 & 0 & 109 & 60.6 & $\mathrm{U}$ \\
\hline 5 & Item 5 & 0 & 2 & 34 & 0 & 0 & 106 & 58.9 & QU \\
\hline 6 & Item 6 & 0 & 2 & 33 & 1 & 0 & 107 & 59.4 & QU \\
\hline 7 & Item 7 & 0 & 0 & 29 & 7 & 0 & 115 & 63.9 & $\mathrm{U}$ \\
\hline 8 & Item 8 & 0 & 0 & 36 & 0 & 0 & 108 & 60 & $\mathrm{U}$ \\
\hline 9 & Item 9 & 0 & 0 & 35 & 1 & 0 & 109 & 60.6 & $\mathrm{U}$ \\
\hline 10 & Item 10 & 0 & 4 & 32 & 0 & 0 & 104 & 57.8 & QU \\
\hline 11 & Item 11 & 0 & 1 & 35 & 0 & 0 & 107 & 59.4 & QU \\
\hline 12 & Item 12 & 0 & 5 & 28 & 3 & 0 & 106 & 58.9 & QU \\
\hline 13 & Item 13 & 0 & 2 & 34 & 0 & 0 & 106 & 58.9 & QU \\
\hline 14 & Item 14 & 0 & 1 & 26 & 9 & 0 & 116 & 64.4 & $\mathrm{U}$ \\
\hline 15 & Item 15 & 0 & 9 & 24 & 3 & 0 & 102 & 56.7 & QU \\
\hline 16 & Item 16 & 0 & 24 & 12 & 0 & 0 & 84 & 46.7 & QU \\
\hline & Total & & & & & & 1664 & 924.5 & \\
\hline & Average & & & & & & 104 & 57.8 & QU \\
\hline
\end{tabular}

Soure: Data Analysis, 2017

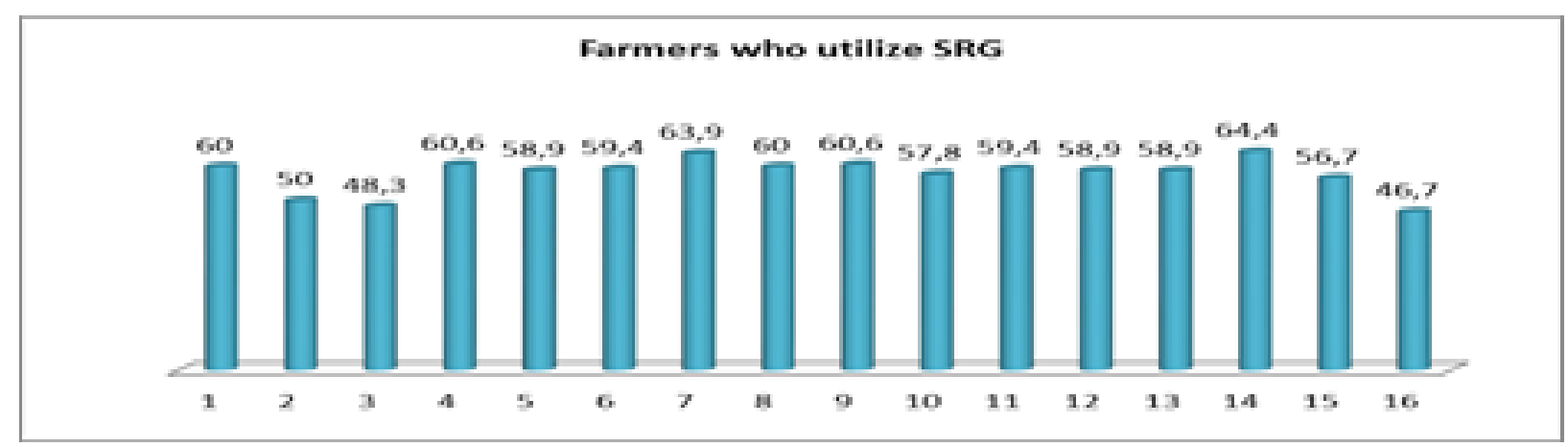

Figure 1: described percentages of the respondents' answers in a diagram. 
Based on Table 6 and Figure 1, it can be explained that

1) Item 1 with total score of 108 or $60 \%$ showed that the respondents know the existence of WRS. They could show the location of the warehouses while the Department of Trade and its staffs provided the farmers with information on WRS.

2) Item 2 with total score of 90 or $50 \%$ showed that the respondents had good understanding on the definition of WRS even though it did not meant that they knew the definition of WRS and the warehouse receipt.

3) Item 3 with total score of 87 or $48.33 \%$ showed that the respondents had good level of understanding about WRS rules. Most of them knew that WRS was established based on legal basis of operation but they did not specifically mention the WRS regulation properly and completely.

4) Item 4 with total score of 109 or $60.6 \%$ meant the respondents had good understanding on WRS benefit such as stabilizing food commodity price. WRS helped farmers overcome declining price of food commodity during harvest time.

5) Item 5 with total score of 106 or $58.9 \%$ means showed that the respondents understood role of WRSin minimizing fluctuation of grain and corn prices. Farmers could temporarily store their goods in the warehouses until prices of food commodity getting back to normal. In other words, the storage helped farmers reducing risk of business failure.

6) Item 6 with total score of 107 or 59.4\%) showed that the respondents had good understanding on WRS' role as alternative marketing solution.

7) Item 7 with total score of 115 or $63.9 \%$ showed that the respondents understood type of commodities to store in the warehouses. The majority of respondents mentioned grain, corn, and rice as types of food commodity to store in the storage units. Only a small number of the respondents stated that farmers may store coffee or chocolate there.

8) Item 8 with total score of 108 or $60 \%$ ) showed that the respondents understood that they would get receipt after their goods in the warehouse, and they could use this receipt as inventory collateral. They could borrow some moneyin the bank to buy their daily needor plan the next farming season.

9) Item 9 with total score of 109 or $60.6 \%$ ) showed that the respondents understood that storing their harvest in the warehouse would minimize some damage caused by pest (rats, birds, etc.) or other factors such as flood, fire, and theft.

10) Item 10 with total score of 104 or $57.8 \%$ showed that the respondents had good understanding that the commodities stored in the warehouses were covered by insurance.

11) Item 11 with total score of 107 or $59.4 \%$ ) showed that the respondents understood that WRS policy was solution for issues related to funding. The farmers had difficulties to get some capital. They could use the warehouse receipt to borrow money in the banks or other financial institutions. They could borrow as much as $70 \%$ of the prices of their stored items.

12) Item 12 with total score of 106 or $58.9 \%$ ) showed that the respondents understood the WRS facilities. They had the rights to get well-maintained warehouse. In addition, the farmers should get most current information on the price of the stored commodity, including quality test results conducted by certain institutions such as "Bulog."

13) Item 13 with total score of 106 or $58.9 \%$ showed that the respondents had fair understanding on the warehouse service system. According to them, the managers should be skillful, friendly, and responsive. These three personality traits would attract farmers to store grain or corn in the warehouse. 
14) Item 14 with total score of 116 or $64.4 \%$ showed that the respondents had good level of understanding on number of days to publish warehouse receipt. Most of them mentioned that the waiting time was between 1 and 2 days.

15) Item 15 with total score of 102 or $56.7 \%$ ) showing that the respondents had fair understanding on the procedures of storing goods in the warehouse. It started from taking the grain or corn) to the warehouse, weighing them, drying them either under the sunor using dryer, conducting quality control test and finally, publishing the receipt.

16) Item 16 with total score of 84 or $46.7 \%$ ) showed that the respondents had fair understanding about institution/individual associated to the warehouse receipt system. They were warehouse manager, financial guarantee institution (bank), and quality control staffs.

Having obtained data from 36 WRS users from six areaa in East Java, it was concluded that item 14, waiting time to publish WRS receipt, had the highest percentage (64.4\%), while item 16, nstitution/individual associated to the warehouse receipt system, had the lowest percentage (46.7\%). The average total score was 104 or 57.8\% showed that the WRS users in East Java had fair understanding towards the Warehouse Receipt System. Related institutions such as Department of Trade and Department of Agriculture are the ones who spread information about WRS.

\subsection{Non WRS Users' Understanding on the Warehouse Receipt System}

\section{Probolinggo}

Table 7: Non WRS Users' Understanding on WRS Policy in Probolinggo

\begin{tabular}{|c|c|c|c|c|c|c|c|c|c|}
\hline \multirow[b]{2}{*}{ No } & \multirow[b]{2}{*}{ Question } & \multicolumn{5}{|c|}{ Number of Respondents' Answers } & \multirow[b]{2}{*}{$\begin{array}{l}\text { Total } \\
\text { score }\end{array}$} & \multirow{2}{*}{$\begin{array}{l}\text { Score } \\
\text { Interpretation } \\
(\%)\end{array}$} & \multirow[b]{2}{*}{ Criteria } \\
\hline & & $\begin{array}{l}\text { VUF } \\
=1\end{array}$ & $\begin{array}{l}\text { DNU } \\
=2\end{array}$ & $\begin{array}{l}\text { QU } \\
=\mathbf{3}\end{array}$ & $\begin{array}{l}\mathrm{U} \\
=4\end{array}$ & $\begin{array}{l}\text { VU } \\
=5\end{array}$ & & & \\
\hline 1 & Item 1 & 0 & 10 & 0 & 0 & 0 & 20 & 40 & $\mathrm{QU}$ \\
\hline 2 & Item 2 & 3 & 7 & 0 & 0 & 0 & 17 & 34 & DNU \\
\hline 3 & Item 3 & 4 & 6 & 0 & 0 & 0 & 16 & 32 & DNU \\
\hline 4 & Item 4 & 0 & 8 & 2 & 0 & 0 & 22 & 44 & QU \\
\hline 5 & Item 5 & 4 & 6 & 0 & 0 & 0 & 16 & 32 & DNU \\
\hline 6 & Item 6 & 0 & 10 & 0 & 0 & 0 & 20 & 40 & DNU \\
\hline 7 & Item 7 & 0 & 0 & 10 & 0 & 0 & 30 & 60 & $\mathrm{U}$ \\
\hline 8 & Item 8 & 3 & 6 & 1 & 0 & 0 & 18 & 36 & DNU \\
\hline 9 & Item 9 & 0 & 3 & 7 & 0 & 0 & 27 & 54 & QU \\
\hline 10 & Item 10 & 7 & 3 & 0 & 0 & 0 & 13 & 26 & DNU \\
\hline 11 & Item 11 & 1 & 9 & 0 & 0 & 0 & 19 & 38 & DNU \\
\hline 12 & Item 12 & 4 & 6 & 0 & 0 & 0 & 16 & 32 & DNU \\
\hline 13 & Item 13 & 0 & 8 & 2 & 0 & 0 & 22 & 44 & QU \\
\hline 14 & Item 14 & 2 & 8 & 0 & 0 & 0 & 18 & 36 & DNU \\
\hline 15 & Item 15 & 5 & 5 & 0 & 0 & 0 & 15 & 30 & DNU \\
\hline 16 & Item 16 & 5 & 5 & 0 & 0 & 0 & 15 & 30 & DNU \\
\hline & Total & & & & & & 304 & 608 & \\
\hline & Average & & & & & & 19 & 38 & QU \\
\hline
\end{tabular}

Source: Data Analysis, 2017 
The number of respondents in Probolinggo was 10 respondents Item 7 got the highest score (30 or $60 \%$ ) showing that non WRS users understood the types of commodities to store in the warehouse. Item 10 got the lowest total score (13 is or $26 \%$ ) showing that the non WRS users did not understand about insurance cover for the stored commodities. They were not aware about this information because they never used the storage units before. The average score was 19 or $38 \%$ which showed non WRS users lacking understanding on the WRS policy.

\section{Sampang}

Table 8: Non WRS Users' on WRS Policy in Sampang

\begin{tabular}{|c|c|c|c|c|c|c|c|c|c|}
\hline \multirow[b]{2}{*}{ No } & \multirow[b]{2}{*}{ Question } & \multicolumn{5}{|c|}{ Number of Respondents' Answers } & \multirow[b]{2}{*}{$\begin{array}{l}\text { Total } \\
\text { score }\end{array}$} & \multirow{2}{*}{$\begin{array}{l}\text { Score } \\
\text { Interpretation } \\
(\%)\end{array}$} & \multirow[b]{2}{*}{ Criteria } \\
\hline & & $\begin{array}{l}\text { VUF } \\
=1\end{array}$ & $\begin{array}{l}\text { DNU } \\
=2\end{array}$ & $\begin{array}{l}\text { QU } \\
=3\end{array}$ & $\begin{array}{l}\mathrm{U} \\
=4\end{array}$ & $\begin{array}{l}\text { VU } \\
=5\end{array}$ & & & \\
\hline 1 & Item 1 & 0 & 10 & 0 & 0 & 0 & 20 & 40 & QU \\
\hline 2 & Item 2 & 5 & 5 & 0 & 0 & 0 & 15 & 30 & DNU \\
\hline 3 & Item 3 & 2 & 8 & 0 & 0 & 0 & 18 & 36 & DNU \\
\hline 4 & Item 4 & 0 & 7 & 3 & 0 & 0 & 23 & 46 & QU \\
\hline 5 & Item 5 & 2 & 8 & 0 & 0 & 0 & 18 & 36 & DNU \\
\hline 6 & Item 6 & 0 & 8 & 2 & 0 & 0 & 22 & 44 & QU \\
\hline 7 & Item 7 & 0 & 0 & 10 & 0 & 0 & 30 & 60 & $\mathrm{U}$ \\
\hline 8 & Item 8 & 2 & 6 & 2 & 0 & 0 & 20 & 40 & QU \\
\hline 9 & Item 9 & 0 & 7 & 3 & 0 & 0 & 23 & 46 & QU \\
\hline 10 & Item 10 & 7 & 3 & 0 & 0 & 0 & 13 & 26 & DNU \\
\hline 11 & Item 11 & 2 & 7 & 1 & 0 & 0 & 19 & 38 & DNU \\
\hline 12 & Item 12 & 0 & 7 & 3 & 0 & 0 & 23 & 46 & QU \\
\hline 13 & Item 13 & 1 & 9 & 0 & 0 & 0 & 19 & 38 & DNU \\
\hline 14 & Item 14 & 1 & 6 & 3 & 0 & 0 & 22 & 44 & QU \\
\hline 15 & Item 15 & 3 & 7 & 0 & 0 & 0 & 17 & 34 & DNU \\
\hline 16 & Item 16 & 4 & 6 & 0 & 0 & 0 & 16 & 32 & DNU \\
\hline & Total & & & & & & 318 & 636 & \\
\hline & Average & & & & & & 19.9 & 39.7 & DNU \\
\hline
\end{tabular}

Source: Data Analysis, 2017

The number of respondents in Probolinggo was 10 respondents. Item 7 had the highest score (30 or $60 \%$ ) which meant that the non WRS users had good understanding towards type of commodities to store in the warehouses. Item 10 hadthe lowest score (13 or 26\%), meaning that the non WRS users fdid not understand about insurance cover for the stored commodities. They were not aware about these information because they never used the storage units The average total score was 19.9 or $39.75 \%$ showing non WRS users lacking understanding about WRS policy. 
Situbondo

Table 9: Non WRS Users' Understanding on WRS Policy in Situbondo

\begin{tabular}{|c|c|c|c|c|c|c|c|c|c|}
\hline \multirow[b]{2}{*}{ No } & \multirow[b]{2}{*}{ Question } & \multicolumn{5}{|c|}{ Number of Respondents' Answers } & \multirow[b]{2}{*}{$\begin{array}{l}\text { Total } \\
\text { score }\end{array}$} & \multirow{2}{*}{$\begin{array}{l}\text { Score } \\
\text { Interpretation } \\
(\%)\end{array}$} & \multirow[b]{2}{*}{ Criteria } \\
\hline & & $\begin{array}{l}\text { VUF } \\
=1\end{array}$ & $\begin{array}{l}\text { DNU } \\
=2\end{array}$ & $\begin{array}{l}\mathbf{Q U} \\
=3\end{array}$ & $\begin{array}{l}\mathrm{U} \\
=4\end{array}$ & $\begin{array}{l}\mathrm{VU} \\
=5\end{array}$ & & & \\
\hline 1 & Item 1 & 4 & 5 & 1 & 0 & 0 & 17 & 34 & DNU \\
\hline 2 & Item 2 & 2 & 8 & 0 & 0 & 0 & 18 & 36 & DNU \\
\hline 3 & Item 3 & 4 & 6 & 0 & 0 & 0 & 16 & 32 & DNU \\
\hline 4 & Item 4 & 2 & 7 & 1 & 0 & 0 & 19 & 38 & DNU \\
\hline 5 & Item 5 & 1 & 9 & 0 & 0 & 0 & 19 & 38 & DNU \\
\hline 6 & Item 6 & 2 & 7 & 1 & 0 & 0 & 19 & 38 & $\mathrm{DNU}$ \\
\hline 7 & Item 7 & 0 & 2 & 8 & 0 & 0 & 28 & 56 & QU \\
\hline 8 & Item 8 & 3 & 6 & 1 & 0 & 0 & 18 & 36 & DNU \\
\hline 9 & Item 9 & 0 & 5 & 5 & 0 & 0 & 25 & 50 & QU \\
\hline 10 & Item 10 & 0 & 10 & 0 & 0 & 0 & 20 & 40 & QU \\
\hline 11 & Item 11 & 2 & 8 & 0 & 0 & 0 & 18 & 36 & DNU \\
\hline 12 & Item 12 & 2 & 6 & 2 & 0 & 0 & 20 & 40 & $\mathrm{QU}$ \\
\hline 13 & Item 13 & 0 & 10 & 0 & 0 & 0 & 20 & 40 & QU \\
\hline 14 & Item 14 & 2 & 8 & 0 & 0 & 0 & 18 & 36 & DNU \\
\hline 15 & Item 15 & 5 & 5 & 0 & 0 & 0 & 15 & 30 & DNU \\
\hline 16 & Item 16 & 5 & 5 & 0 & 0 & 0 & 15 & 30 & DNU \\
\hline & Total & & & & & & 305 & 610 & \\
\hline & Average & & & & & & 19 & 38.1 & DNU \\
\hline
\end{tabular}

Source: Data Analysis, 2017

The number of respondents in Situbondo was 10 respondents. Item 7 had the highest total score ( 28 or $56 \%$ ) showing that the non WRS users had good understanding towards type of commodities to store in the warehouse. Item 15 and 16 had the lowest total score (15 or $30 \%$ each), meaning that non WRS users did not understand either the storing procedures in the warehouses or institutions/ individuals associated to WRS. This is reasonable because the farmers never used the warehouses. The average total score was 19 or $38.1 \%$ showing non WRS users lacking understanding on the overall WRS policy.

\section{Nganjuk}

Table 10: Non WRS Users' Understanding on WRS Policy in Nganjuk

\begin{tabular}{|c|c|c|c|c|c|c|c|c|c|}
\hline \multirow[b]{2}{*}{ No } & \multirow[b]{2}{*}{ Question } & \multicolumn{5}{|c|}{ Number of Respondents' Answers } & \multirow[b]{2}{*}{$\begin{array}{l}\text { Total } \\
\text { score }\end{array}$} & \multirow{2}{*}{$\begin{array}{l}\text { Score } \\
\text { Interpretation } \\
(\%)\end{array}$} & \multirow[b]{2}{*}{ Criteria } \\
\hline & & $\begin{array}{l}\begin{array}{l}\text { VUF } \\
=1\end{array} \\
\end{array}$ & $\begin{array}{l}\text { DNU } \\
=2\end{array}$ & $\begin{array}{l}\text { QU } \\
=3\end{array}$ & $\begin{array}{l}\mathrm{U} \\
=4\end{array}$ & $\begin{array}{l}\text { VU } \\
=5\end{array}$ & & & \\
\hline 1 & Item 1 & 1 & 8 & 1 & 0 & 0 & 20 & 40 & QU \\
\hline 2 & Item 2 & 5 & 5 & 0 & 0 & 0 & 15 & 30 & DNU \\
\hline 3 & Item 3 & 1 & 9 & 0 & 0 & 0 & 19 & 34 & DNU \\
\hline 4 & Item 4 & 2 & 8 & 0 & 0 & 0 & 18 & 36 & DNU \\
\hline 5 & Item 5 & 2 & 6 & 2 & 0 & 0 & 20 & 40 & QU \\
\hline
\end{tabular}




\begin{tabular}{|l|l|l|l|l|l|l|l|l|l|}
\hline 6 & Item 6 & 1 & 9 & 0 & 0 & 0 & 19 & 38 & DNU \\
\hline 7 & Item 7 & 0 & 0 & 10 & 0 & 0 & 30 & 60 & U \\
\hline 8 & Item 8 & 0 & 7 & 3 & 0 & 0 & 23 & 46 & QU \\
\hline 9 & Item 9 & 0 & 6 & 4 & 0 & 0 & 24 & 48 & QU \\
\hline 10 & Item 10 & 3 & 7 & 0 & 0 & 0 & 17 & 34 & DNU \\
\hline 11 & Item 11 & 2 & 8 & 0 & 0 & 0 & 18 & 36 & DNU \\
\hline 12 & Item 12 & 1 & 9 & 0 & 0 & 0 & 19 & 38 & DNU \\
\hline 13 & Item 13 & 1 & 9 & 0 & 0 & 0 & 19 & 38 & DNU \\
\hline 14 & Item 14 & 2 & 7 & 1 & 0 & 0 & 19 & 38 & DNU \\
\hline 15 & Item 15 & 2 & 8 & 0 & 0 & 0 & 18 & 36 & DNU \\
\hline 16 & Item 16 & 8 & 2 & 0 & 0 & 0 & 12 & 24 & DNU \\
\hline & Total & & & & & & 310 & 616 & DNU \\
\hline & Average & & & & & & 19.4 & 38.5 & \\
\hline
\end{tabular}

Sourcer: Data Analysis, 2017

The number of respondents in Nganjuk was 10 respondents. Item 7 had the highest total score (30 or 60\%) which showed that the non WRS users had good understanding towards type of commodities to store in the warehouse. Item 16 had the lowest total score (12 or 24\%) meaning that the non WRS users did not understand institutions or individual associated to WRS. The average total score was 19.4 or $38.5 \%$ showing non WRS users lacking understanding on the overall WRS policy.

\section{Madiun}

Table 11: Non WRS Users' Understanding on WRS Policy in Madiun

\begin{tabular}{|c|c|c|c|c|c|c|c|c|c|}
\hline \multirow[b]{2}{*}{ No } & \multirow[b]{2}{*}{ Question } & \multicolumn{5}{|c|}{ Number of Respondents' Answers } & \multirow[b]{2}{*}{$\begin{array}{l}\text { Total } \\
\text { score }\end{array}$} & \multirow{2}{*}{$\begin{array}{l}\text { Score } \\
\text { Interpretation } \\
(\%)\end{array}$} & \multirow[b]{2}{*}{ Criteria } \\
\hline & & $\begin{array}{l}\text { VUF } \\
=1\end{array}$ & $\begin{array}{l}\text { DNU } \\
=2\end{array}$ & $\begin{array}{l}\text { QU } \\
=3\end{array}$ & $\begin{array}{l}\mathrm{U} \\
=4\end{array}$ & $\begin{array}{l}\mathrm{VU} \\
=5\end{array}$ & & & \\
\hline 1 & Item 1 & 0 & 8 & 2 & 0 & 0 & 22 & 44 & QU \\
\hline 2 & Item 2 & 2 & 8 & 0 & 0 & 0 & 18 & 36 & DNU \\
\hline 3 & Item 3 & 2 & 8 & 0 & 0 & 0 & 18 & 36 & DNU \\
\hline 4 & Item 4 & 1 & 7 & 2 & 0 & 0 & 21 & 42 & QU \\
\hline 5 & Item 5 & 0 & 7 & 3 & 0 & 0 & 23 & 46 & QU \\
\hline 6 & Item 6 & 1 & 8 & 1 & 0 & 0 & 20 & 40 & QU \\
\hline 7 & Item 7 & 0 & 1 & 9 & 0 & 0 & 29 & 58 & QU \\
\hline 8 & Item 8 & 1 & 7 & 2 & 0 & 0 & 21 & 42 & QU \\
\hline 9 & Item 9 & 0 & 6 & 4 & 0 & 0 & 24 & 48 & QU \\
\hline 10 & Item 10 & 1 & 9 & 0 & 0 & 0 & 19 & 38 & $\mathrm{DNU}$ \\
\hline 11 & Item 11 & 1 & 7 & 2 & 0 & 0 & 21 & 42 & QU \\
\hline 12 & Item 12 & 1 & 8 & 1 & 0 & 0 & 20 & 40 & QU \\
\hline 13 & Item 13 & 8 & 2 & 0 & 0 & 0 & 12 & 24 & DNU \\
\hline 14 & Item 14 & 4 & 4 & 2 & 0 & 0 & 18 & 36 & DNU \\
\hline 15 & Item 15 & 1 & 8 & 1 & 0 & 0 & 20 & 40 & QU \\
\hline 16 & Item 16 & 2 & 8 & 0 & 0 & 0 & 18 & 36 & DNU \\
\hline & Total & & & & & & 324 & 648 & \\
\hline
\end{tabular}




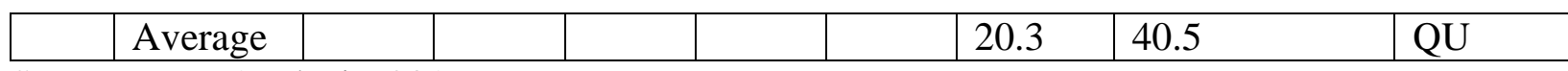

Source: Data Analysis, 2017

The number of respondents in Madiun was 10 respondents. Item 7 had the highest total score (29 or 58\%) meaning that the non WRS users had good understanding towards type of commodities to store in the warehouse. Item 16 had the lowest total score (11 or 22\%) meaning that the non WRS users did not understand institutionor individual associated to WRS. The average total score was 20.3 or $40.5 \%$ which showed that the non WRS users had fair understanding on the WRS policy, even though they never took advantage of the storage units.

\section{Tuban}

Table 12: Non WRS Users' Understanding on WRS Policy in Tuban

\begin{tabular}{|c|c|c|c|c|c|c|c|c|c|}
\hline \multirow[b]{2}{*}{ No } & \multirow[b]{2}{*}{ Question } & \multicolumn{5}{|c|}{ Number of Respondents' Answers } & \multirow[b]{2}{*}{$\begin{array}{l}\text { Total } \\
\text { score }\end{array}$} & \multirow{2}{*}{$\begin{array}{l}\text { Score } \\
\text { Interpretation } \\
(\%)\end{array}$} & \multirow[b]{2}{*}{ Criteria } \\
\hline & & $\begin{array}{l}\text { VUF } \\
=1\end{array}$ & $\begin{array}{l}\text { DNU } \\
=2\end{array}$ & $\begin{array}{l}\text { QU } \\
=\mathbf{3}\end{array}$ & $\begin{array}{l}\mathrm{U} \\
=4\end{array}$ & $\begin{array}{l}\mathrm{VU} \\
=5\end{array}$ & & & \\
\hline 1 & Item 1 & 0 & 7 & 3 & 0 & 0 & 23 & 46 & QU \\
\hline 2 & Item 2 & 1 & 9 & 0 & 0 & 0 & 19 & 38 & DNU \\
\hline 3 & Item 3 & 2 & 8 & 0 & 0 & 0 & 18 & 36 & DNU \\
\hline 4 & Item 4 & 1 & 9 & 0 & 0 & 0 & 19 & 38 & DNU \\
\hline 5 & Item 5 & 3 & 6 & 1 & 0 & 0 & 18 & 36 & DNU \\
\hline 6 & Item 6 & 3 & 6 & 1 & 0 & 0 & 18 & 36 & DNU \\
\hline 7 & Item 7 & 0 & 0 & 10 & 0 & 0 & 30 & 60 & $\mathrm{U}$ \\
\hline 8 & Item 8 & 1 & 7 & 2 & 0 & 0 & 21 & 42 & QU \\
\hline 9 & Item 9 & 0 & 0 & 10 & 0 & 0 & 30 & 60 & $\mathrm{U}$ \\
\hline 10 & Item 10 & 0 & 6 & 4 & 0 & 0 & 24 & 48 & QU \\
\hline 11 & Item 11 & 0 & 8 & 2 & 0 & 0 & 22 & 44 & QU \\
\hline 12 & Item 12 & 1 & 9 & 0 & 0 & 0 & 19 & 38 & DNU \\
\hline 13 & Item 13 & 0 & 9 & 1 & 0 & 0 & 21 & 42 & QU \\
\hline 14 & Item 14 & 0 & 9 & 1 & 0 & 0 & 21 & 42 & QU \\
\hline 15 & Item 15 & 0 & 10 & 0 & 0 & 0 & 20 & 40 & QU \\
\hline 16 & Item 16 & 9 & 1 & 0 & 0 & 0 & 11 & 22 & DNU \\
\hline & Total & & & & & & 334 & 668 & \\
\hline & Average & & & & & & 20.9 & 41.8 & QU \\
\hline
\end{tabular}

Source: Data Analysis, 2017

The number of respondents in Tuban was 10 respondents. Item 7 had the highest total score (30 or $60 \%$ ) meaning that the non WRS users had good understanding towards type of commodities to store in the warehouse. Item 16 had the lowest total score (11 or 22\%) showing the farmers lack of understanding on the institution/ individual associated to WRS. The average total score was 20.9 or $41.8 \%$ which showed that the non WRS users had fair understanding on the WRS policy, even though they never took advantage of the storage units.

Table 13 showed the result of the Likert-scale analysis on the data taken from the 60 non WRS users from six municipalities in East Java (Tuban, Madiun, Nganjuk, Sampang, Probolinggo, and Situbondo). 
Jawa Timur (East Java)

Table 13: Non WRS Users' Understanding on WRS Policy in East Java

\begin{tabular}{|c|c|c|c|c|c|c|c|c|c|}
\hline \multirow[b]{2}{*}{ No } & \multirow[b]{2}{*}{ Question } & \multicolumn{5}{|c|}{ Number of Respondents' Answers } & \multirow[b]{2}{*}{$\begin{array}{l}\text { Total } \\
\text { score }\end{array}$} & \multirow{2}{*}{$\begin{array}{l}\text { Score } \\
\text { Interpretation } \\
(\%)\end{array}$} & \multirow[b]{2}{*}{ Criteria } \\
\hline & & $\begin{array}{l}\text { VUF } \\
=1\end{array}$ & $\begin{array}{l}\text { DNU } \\
=2\end{array}$ & $\begin{array}{l}\text { QU } \\
=\mathbf{3}\end{array}$ & $\begin{array}{l}\mathrm{U} \\
=4\end{array}$ & $\begin{array}{l}\text { VU } \\
=5\end{array}$ & & & \\
\hline 1 & Item 1 & 5 & 48 & 7 & 0 & 0 & 122 & 40.7 & QU \\
\hline 2 & Item 2 & 18 & 42 & 0 & 0 & 0 & 102 & 34 & DNU \\
\hline 3 & Item 3 & 15 & 45 & 0 & 0 & 0 & 105 & 35 & DNU \\
\hline 4 & Item 4 & 6 & 46 & 8 & 0 & 0 & 122 & 40.7 & QU \\
\hline 5 & Item 5 & 12 & 42 & 6 & 0 & 0 & 114 & 38 & DNU \\
\hline 6 & Item 6 & 7 & 48 & 5 & 0 & 0 & 118 & 39.3 & DNU \\
\hline 7 & Item 7 & 0 & 3 & 57 & 0 & 0 & 177 & 59 & QU \\
\hline 8 & Item 8 & 10 & 39 & 11 & 0 & 0 & 121 & 40.3 & QU \\
\hline 9 & Item 9 & 0 & 27 & 33 & 0 & 0 & 153 & 51 & QU \\
\hline 10 & Item 10 & 18 & 38 & 4 & 0 & 0 & 106 & 35.3 & DNU \\
\hline 11 & Item 11 & 8 & 47 & 5 & 0 & 0 & 117 & 39 & DNU \\
\hline 12 & Item 12 & 9 & 45 & 6 & 0 & 0 & 117 & 39 & DNU \\
\hline 13 & Item 13 & 10 & 47 & 3 & 0 & 0 & 113 & 37.7 & DNU \\
\hline 14 & Item 14 & 11 & 42 & 7 & 0 & 0 & 116 & 38.7 & DNU \\
\hline 15 & Item 15 & 16 & 43 & 1 & 0 & 0 & 105 & 35 & DNU \\
\hline 16 & Item 16 & 33 & 27 & 0 & 0 & 0 & 87 & 29 & DNU \\
\hline & Total & & & & & & 1895 & 631.7 & \\
\hline & Average & & & & & & 118.4 & 39.5 & DNU \\
\hline
\end{tabular}

Source: Data Analysis, 2017

Figure 2 described percentages of the respondents' answers in a diagram

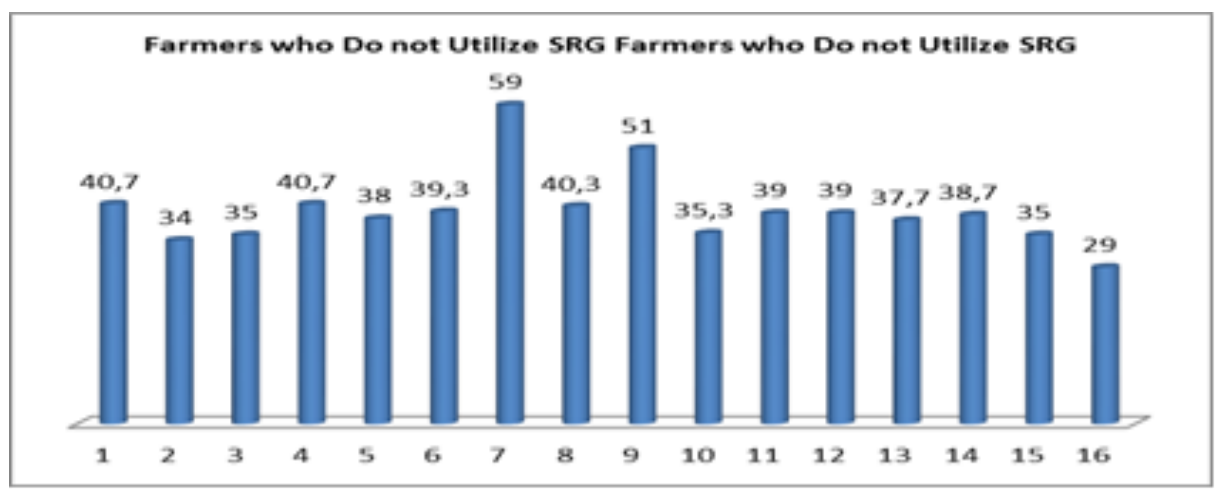

Figure 2: Non WRS User's Understanding on WRS in East Java

Table 13 and Figure 2 above explained that

1) Item 1 with total score of 122 or $40.7 \%$ indicated that the respondents had fair understanding about existence of WRS. They were able to mention location of the WRS warehouse even though they did not use it.

2) Item 2 with total score of 102 or $34 \%$ indicated that the respondents did not know the definition of WRS 
3) Item 3 with total score of 105 or $35 \%$ indicated that the respondents did not know any rules related to WRS.

4) Item 4 with total score of 122 or $40.7 \%$ indicated that the respondents fairly understood how useful WRS was even though they did not use the warehouse. In their opinion, storing grain or corn in a warehouse for a certain period of time allow them to sell the commodity for a better price offer. However, these farmers generally need money immediately after harvest to for the next farming season or their daily needs.

5) Item 5 with total score of 114 or $38 \%$ indicated that the respondents did not understand that WRS helped overcome fluctuation of grain and corn price and minimizing business failure. The farmers prefered to sell their harvest immediately despite of their low price.

6) Item 6 with total score of 118 or $39.3 \%$ indicated that the respondents did not understand WRS role as alternative marketing solution with delayed selling model.

7) Item 7 with total score 177 of $59 \%$ indicated the respondents fairly understood the kinds of commodities to store in warehouse. According to them, grain, corn, and rice were three food commodities they could store in the warehouses, but they did not understand that the storage units are the place for storing other commodities such as coffee, chocolate, and salt too

8) Item 8 with total score of 121 or $40.3 \%$ indicated that the respondents had fair understanding about warehouse receipt they would get after storing their harvest in the warehouse. However, they had yet understood to use the receipt for other purposes. The farmers were not familiar with the banking system. They associated bank to administrative and bureaucratic complexities. To get capital, these farmers went to middlemen or wholesalers because it does not require complicated administration and long bureaucracy. They would pay their loan after harvest. As the consequence of this loan system, the farmers had to sell their harvest to the middlemen or wholesaler.

9) Item 9 with total score of 153 or $51 \%$ indicated that the respondents fairly understood that the warehouses kept their harvest safe. According to the respondents, security of the goods (from pest such as rats, birds, and lice or other other factors such as flood, fire, and theft) became the responsibility of the warehouse management.

10) Item 10 with total score of 106 or $35.3 \%$ indicated that the respondents did not understand that they would get insurance for the harvest they stored in the warehouse.

11) Item 11 with total score of 117 or $39 \%$ indicated that the respondents did not know that WRS policy helped them raising capital.

12) Item 12 with total score of 117 or $39 \%$ indicated the respondents lacking understanding on the warehouse facilities such as well-maintained storage units, quality control, pricing information, and access to technology. It happened because these respondents had never used the storage unit.

13) Item 13 with total score 113 or $37.7 \%$ showed the respondents lacking understanding on the warehouse service particularly role of the warehouse manager. According to the farmers, providing good service is important because it will attract farmers to keep their goods in the warehouse.

14) Item 14 with total score of 116 or $38.7 \%$ indicated that the respondents did not understand how much time was needed to publish the receipt since they had never taken advantage of the facility.

15) Item 15 with total score of 105 or $35 \%$ showed that the respondents did not understand the WRS procedures. 
16) Item 16 with the lowest total score of 87 or $29 \%$ ) indicated lacking understanding on institution or individual associated to the warehouse receipt system.

Based on table 13 item 7, type of commodities to store in the warehouse, had the highest score (177 or 59\%), while item 16, institution or individual having association to WRS, had the lowest total score (87 or $29 \%$ ). Based on the data obtained, nearly all non WRS users stated they are not aware which institutions or individuals responsible for the WRS. The average total score was 118.4 or $39.5 \%$ showing that the respondents did not understand about the warehouse receipt policy even though it has been established since 2009.

(Therefore, the stakeholders' commitment, the local government's participation, and the private sectors' participation are required to support and develop the WRS management. Basically, all agricultural products need a good post-harvest handling to ensure the quality of the products. It can be done by implementing WRS. This will help farmers gain more benefits. In addition, strengthening the farmer institution is important to make farmers utilize WRS, and it should be evaluated on a regular basis.)

\section{Conclusion}

Based on the finding and discussions, it can be concluded that:

- $\quad$ Based on the WRS users' responses, item 14 that is time allotment to publish the WRS receipt have the highest percentage $(64.4 \%)$. The percentage implies that the farmers understand how many days they have to wait before the receipt is published. On the other hand, item 16 has the lowest percentage (46.7\%) showing that the farmers have fair understanding on institutions/ individuals associated to the WRS institutional.

- $\quad$ Based on the non WRS users' responses, item 7 had the highest percentage $(59 \%)$ that indicates that the farmers understand what type of food commodities to store in the warehouse. Item 10 and 16 have the lowest percentage (36\%). It means the non WRS users do not understand that the goods stored in the warehouse are covered by insurance coverage or institution and individual associated to WRS.

The following aspects are the general conclusion from a study entitled" Farmer's Understanding on the policy of Warehouse Receipt System (WRS) in East Java.

1) Some farmers are not familiar with WRS.

2) In general, Warehouse Receipt system is good system to improve the agricultural sector. However, some farmers still find it difficult to participate in the system

3) Due to their education background a lot of farmers find administrative banking system too complicated

4) Farmers prefer to sell their crops directly because they can get cash immediately.

5) These warehouses are not located very close to the farm or rice field and therefore, cost for transportation is steep. In addition, the farmers have to pay some fee to store their crops. These discourage farmers to use the warehouses

6) Middlemen and wholesaler directly approach the farmers asking them to sell their crops immediately

7) Lending money to middlemen or shark loan has become a tradition

8) Farmers did not get information or socialization about WRS from the related institutions. 


\section{Recommendation}

In order to increase farmers' understanding on Warehouse Receipt System (WRS), apply WRS successfully; make positive contribution to the national development, and increase food supply, the government should take the following steps.

- Develop partnership between the government (public institutions responsible for agricultural sector) and the farmers

- Conduct comprehensive, integrated, and accelerated programs to improve the national agricultural sectors and farmers' financial situation

- Spread information on how effective WRS is as marketing strategy and instrument to raise income

- Build smaller warehouse units or warehouse transit container units

- Transparent WRS management system. WRS storage is funded by the central government but it is built on the regional government's land. As the consequence, the local government does not take full responsibility for the management of WRS.

- Well-maintained storage and storage facilities

- Re-evaluating WRS regulations

- Integrated market and price information systems.

- Government intervention in accommodating and marketing the results.

\section{References}

[1] Hariyani,I., \& Serfianto, D. P. (2010). Resi Gudang Sebagai Jaminan Kredit dan Alat Perdagangan. Jakarta: Sinar Grafika.

[2] Husodo, Siswono. 2004. Membangun Kemandirian Pangan. Yayasan Padamu Negeri. Jakarta.

[3] Kementerian Perdagangan RI. (2006). Undang Undang No.9 Tahun 2006, Tentang Resi Gudang.Jakarta: Kemendag.

[4] Mardikanto, T. 1993. Penyuluhan Pembangunan Pertanian. UNS Press. Surakarta.

[5] Nazir, M. (2013). Metode Penelitian. Bogor: Ghalia Indonesia.

[6] Pusat Kebijakan Perdagangan Dalam Negeri Badan Pengkajian dan Pengembangan Kebijakan Perdagangan Kementerian Perdagangan. (2013). .Analisis Efektifitas Implementasi Sistem Resi Gudang Komoditi Jagung. Jakarta.

[7] Sugiyono. (2009). Statistik Non Parametrik. Bandung: Alfabeta.

[8] Sustyaningrum, E. (2014). Eksistensi Resi Gudang sebagai Lembaga Jaminan di Indonesia. Jurnal Repertorium,ISSN: 2355-2646 volume 1 No 2,Nopember 2014 Solo:UNS. 1(2),

[9] Sudarjat. (2014). Sistem Resi Gudang Komoditas Pangan: Kebijakan dan Impelmentasi, Retrieve from http://www.unpad.ac.id/agenda/ceramah-ilmiah-sistem-resi-gudang-komoditas-pangankebijakan-dan-impelmentasi/,Jatinangor: retrieved

*Corresponding author.

E-mail address: lis_sulistyaningsih@yahoo.com/wibowo.rudi@gmail.com/yulihariyati@ ymail.com/ ita_hani@yahoo.com 